\title{
[D]ie keursnit
}

\begin{tabular}{|c|c|}
\hline \multicolumn{2}{|l|}{$\begin{array}{l}\text { Book Title: } \\
\text { Skryn }\end{array}$} \\
\hline $\begin{array}{l}\text { skryn } \\
* \\
* \\
*\end{array}$ & \\
\hline \multicolumn{2}{|l|}{$\begin{array}{l}\text { Author: } \\
\text { Emma Bekker }\end{array}$} \\
\hline \multicolumn{2}{|c|}{$\begin{array}{l}\text { ISBN: } \\
\text { 978-1-4853-0477-7 }\end{array}$} \\
\hline \multicolumn{2}{|c|}{$\begin{array}{l}\text { Publisher: } \\
\text { Protea Boekhuis, 2015, } \\
\text { R150* } \\
\text { *Book price at the time of the } \\
\text { review }\end{array}$} \\
\hline \multicolumn{2}{|l|}{$\begin{array}{l}\text { Review Title: } \\
\text { [D]ie keursnit }\end{array}$} \\
\hline \multicolumn{2}{|c|}{$\begin{array}{l}\text { Reviewer: } \\
\text { Phil van Schalkwyk }{ }^{1}\end{array}$} \\
\hline \multicolumn{2}{|c|}{$\begin{array}{l}{ }^{1} \text { School of Languages, } \\
\text { North-West University, } \\
\text { South Africa }\end{array}$} \\
\hline \multicolumn{2}{|c|}{$\begin{array}{l}\text { Corresponding author: } \\
\text { Phil van Schalkwyk, phil. } \\
\text { vanschalkwyk@nwu.ac.za }\end{array}$} \\
\hline \multicolumn{2}{|c|}{$\begin{array}{l}\text { How to cite this book } \\
\text { review: } \\
\text { Van Schalkwyk, P., 2017, } \\
\text { '[D]ie keursnit', Literator } \\
\text { 38(1), a1296. https://doi. } \\
\text { org/10.4102/lit.v38i1.1296 }\end{array}$} \\
\hline \multicolumn{2}{|c|}{$\begin{array}{l}\text { Copyright: } \\
\text { (c) 2017. The Authors. } \\
\text { Licensee: AOSIS. This work } \\
\text { is licensed under the } \\
\text { Creative Commons } \\
\text { Attribution License. }\end{array}$} \\
\hline \multicolumn{2}{|l|}{ Read online: } \\
\hline 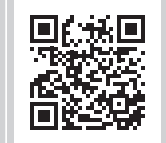 & $\begin{array}{l}\text { Scan this QR } \\
\text { code with your } \\
\text { smart phone or } \\
\text { mobile device } \\
\text { to read online. }\end{array}$ \\
\hline
\end{tabular}

Emma Bekker se debuutdigbundel dra die titel Skryn, 'n woord wat 'n mens vanweë die opvallende kortheid en relatiewe onbekendheid daarvan moontlik aan Marlene van Niekerk (2013) se Kaar kan herinner. Skryn slaan op die ervaring om geskaaf te word, maar kan inderdaad ook beteken bêre- of bewaarplek, en roep daarom, soos 'kaar', ook die semiotiese 'chora' as vroulike ruimte op. Die Nederlandse vorm 'schrijn' (van die Latynse 'scrinium') besit volgens Encyclo.nl (2016), wat agt verskillende woordeboekinskrywings saamvat, verskeie verdere betekenisassosiasies, wat insluit: ' $n$ kissie versier met houtsneewerk waarin kosbaarhede, ook relikwieë, bewaar word. In die verlengde hiervan kan dit dan ook verwys na byvoorbeeld 'n tempel (wat relikwieë bevat), asook meer algemeen: meubels en huisraad.

Hierdie assosiasies, spesifiek die houtsnee-element, kan maklik versoen word met verwante vorme soos 'skrynwerker', 'skaaf' en 'skrynend'. Hierin skuil daar vir die digter bykomend iets ars poëties, naamlik die gedig en die bundel as bewaarplek vir kosbaarhede, wat dan ook die ambagtelike en taal (in hierdie bundel sterk neigend na die taal van gevoel) aktiveer.

Ondersoek toon aan dat 95\% van alle Nederlanders en 98\% van Vlaminge die woord 'schrijn' ken (Woorden.org 2016). Dieselfde geld heel waarskynlik nie vir die Afrikaanse 'skryn' nie. Ek vind die titel van Bekker se bundel wel sinvol, gegewe die tematiek wat daarin aan die bod kom, ook danksy die feit dat sy die meeste betekenisdimensies van die woord 'skryn' netjies integreer by die geheel, maar dit kan dalk effens pretensieus voorkom en strook daarom minder goed met die toeganklikheid wat duidelik in hierdie werk nagestreef word.

Die bundel bestaan uit 'n losstaande openingsgedig, 'Oggendrit deur Linden', en ses afdelings van wisselende boeikrag en gehalte, naamlik 'huisraad', 'soenoffers', 'lyfrede', 'biegbeelde', 'skrynwerk' en 'sleutelsange'.

'Skaaf' kom in hierdie bundel na vore in die dinamiese posisionerings ten opsigte van dit wat die self, veral ook as vrou, omgewe. Die digterspreker teken haarself onder andere as lewensmaat, minnares, moeder, voorstedelike sjamaan, masseerterapeut, Suid-Afrikaanse vrou. Aktualisering van die eie (on)belemmerde bestaan ('Die innerlike mevrou', lui die titel van een van die gedigte), is waaroor dit in hierdie 'onderhandelinge' gaan, nie soseer om 'opruim' nie. Die verkenning van die eie kosbaarheid en / of kosbaarhede word ter wille van selfkennis onderneem, maar ewe sterk teenwoordig is die drang om aan ander iets van die eie lewe, die meublement en huisraad van die persoonlike, te vertoon - in 'Deurbraak' word in hierdie verband gepraat van 'die towerkrag van my eie ontbloting'. Die openingsreël van 'Die geheim van beddens' bevestig hierdie gerigtheid: 'Huisraad berg geheime op maniere wat verras'.

Byna soos Ina Rousseau in die bundel Taxa (vgl. Rousseau 2003) beleef die digterspreker in Skryn die werklikheid vanuit huis en tuin (veral ook die kombuis), maar anders as Rousseau wat haar verkenningstog in harmonie met en gerugsteun deur die kategorieë van die wetenskap onderneem en die vroulike uitbou in die rigting van die wetenskap, is Bekker se benadering meer 'dromend' en 'chaoties' - 'My kop is 'n geraasplaas', lui die openingsreël van 'Die weduwee MacDonald'. Tog, sy kom betreklik naby aan byvoorbeeld 'Die huisvrou' van Rousseau (2003:36) in die vyfde van die reeks 'Kombuiskwatryne':

\footnotetext{
'n Huisvrou kort twee messe om te sny wat sy moet sny:

Vir suiwer klief en skoon ontbeen kort sy 'n groot, swaar lem,

maar 'n delikate krissie is vir kleiner sny bestem -

net ' $n$ fyn lem kan die roos uit die radys bevry.
}

Die mooi poëtikale slotbeeld skakel met die 'relikwieë' in die digterspreker se bestaan: die uitgelese oomblikke, plekke van stilte sowel as haar kinders word beskryf as 'keursnit' en 'kruisskyf' ('kaalvoetstap in stilbaai'). 
'n Gedig soos 'Metabolisme' verwoord heelwat omtrent Bekker se lyflike digterlike aanpak (waarby 'n mens moontlik ook resonansies van T.T. Cloete kan herken, veral 'Vraagteken van die maag' uit sy tweede bundel Jukstaposisie en 'die drie stadia' en 'Brueghel bestry Descartes en Kant' uit Karnaval en Lent):

Ek het vergeefs probeer om uit my kop uit te skryf, om konfyt te kook met net die vrugte van my verstand. My rosige appelkose en blosende pere

het geblus onder lewensdruk

tot aaskewers en haelgewere,

versinsels in 'n tamelet van sinne verstrik.

Verteer is die beste verweer.

Ek soek my oes in ander oorde,

my woorde word gepluk in die boorde

van die maag,

waar suur die sinne opvreet.

Hier word dit wat groots is afgekook,

en dit wat opgeneem word magies.

Dat die onkonvensionele vrou wat in hierdie bundel aan die woord is haar behoorlik tuis voel in haar 'domein' en daarvandaan, en met haar wortels stewig daarin geplant, meestal daarin slaag om seëvierend te leef, spreek uit die bundelverloop en uit spesifieke gedigte soos 'Tuinode', 'n parodie op Langenhoven se 'Die Stem' waarin téén die grein van die oorspronklike teks, gelokaliseer en verpersoonlik word in die rigting van die 'eie groen kokon'. Ander voorbeelde van hierdie gerigtheid is die merendeels geslaagde 'Kombuiskwatryne' (met doelbewuste intertekstuele toespeling onder meer op Boerneef) en die digterlik effens wankelmoedige 'Die digteres as masseuse'. Die slotkoeplet van 'teen onaardigheid' lui, weliswaar met 'n knypie ironie daaraan toegevoeg: 'waar vind ek 'n verweer teen hierdie bewerige melancholie? / in die walms van wierook, mirre en neroli'. In die meer geslaagde gedigte gaan dit nie net oor die vertel oor / van persoonlike sege nie, maar word dit ook digterlik waar gemaak, soos in 'Swaardsmee' waarin die deurlopende lemmotief in die bundel deeglik gekonsolideer word. Vergelyk die eerste strofe:

Die trane van melancholie,

die glip van gal en slym en bloed,

is die olie op die steen

wat'n groot swaard slyp tot hoër diens.

In 'Granaatdig', opgedra aan Pirow Bekker, word die gedig beskryf as 'gedeelde granaat'. Om 'n granaat geëet te kry, 'moet [jy] jou vat en breek ken en weet / wanneer jy 'n lem moet indruk of 'n pen uitruk'. Die slotstrofe verklaar:

Ons verkies die outydse granate,

wat met die rypwordslag

oopbars en karmosyn tande wys.

Die gedig wat my seker die langste sal bybly, is die betreklik sterk eerste afdeling se openingsgedig 'een nag op 'n trein na pretoria', wat met geringer toespeling op die Briels as wat die titel sou laat vermoed, op 'n ontwapenende wyse vertel van ' $n$ treinrit wat die digterspreker as kind in die geselskap van haar swanger moeder meegemaak het, en waartydens sy die heel eerste keer met appelkose ('oupakose', soos sy dit gehoor het) kennismaak - 'hulle proe soos 'n mooi nuwe woord'. Saam met die afbeelding van die 'tas mahaal' (Taj Mahal) op haar krytblik, skakel hierdie ontdekking met die blywende, dromerige liefde vir eksotiese dinge wat haar moeder destyds reeds in haar herken het. Die eksotiese word egter deurgaans gekoppel aan die vertroude (die krytblik), verhuislik ('oupakoos') en op eie voorwaardes ontmoet (in plaas van mooi dankie sê vir die 'geldjie soos 'n blommetjie / met 'n gaatjie in die middel' wat 'n medereisiger haar present gee, kyk sy '... na die krytblik en sê / vertel nog van die tas mahaal').

Die losstaande openingskwatryn van Skryn kondig die breë aandagpunte van hierdie bundel helder aan, naamlik die spanning van die verhewene en die gewone, die verre en die nabye, ensovoorts:

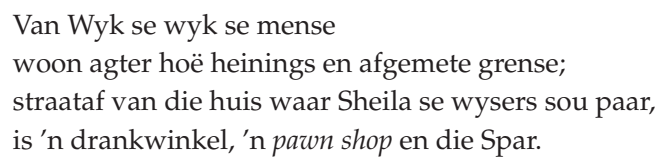

Juis vanweë gewone werklikhede en probleme is die dromende gerigtheid / onderneming nie vry van dinge wat 'die weg van skoon droom belemmer' ('Tweede wittebrood') nie.

Soos blyk uit die bespreking tot dusver, is die tematiek en breë bundelsamestelling voldoende geïntegreerd en onderhoudend. Op die glyskaal van verdienstelikheid hel die bundel egter dalk oor na minder geslaagd, grootliks vanweë tekortkominge wat betref taal en tegniek. Heelwat gedigte misluk as geheel, en van die beter gedigte word ondermyn deur troebelhede.

Oor sommige gedigte sou lesers hulle kon afvra wat die doel van die optekening was, byvoorbeeld die kwatryn 'die keiser sonder klere' wat sluit met: 'soos die man wat sonder onderbroek / sy redding in geweld gaan soek'. In 'Kalkoen in die kragdrade' is die droom wat ná die slordige aankondiging 'soos byvoorbeeld gisternag' verhaal word presies so vervelig soos die aanhoor van ander se drome gewoonlik is. Die refrein in 'Ode aan Marie Laveau' is te karig om herhaling te regverdig.

Bekker beoefen in Skryn merendeels die vrye vers, maar het ook 'n voorliefde vir rym. Soms word die rym wel betreklik vaardig aangewend, maar dikwels is die rymkeuses en dit wat daarmee saamgaan, redelik twyfelagtig, byvoorbeeld in 'Ode aan Marie Laveau' die versreëls: 'En net soos 'n orkaan sal Marie kom en gaan, / maar haar gees laat steeds soekers se hare regop staan'. Deel een van 'Ontwyde moeder' lui:

Maria sien die engel -

sy het hom nie verwag nie.

Maria glo die engel -

maar haar sitplek is nie sag nie. 
Die tweedelige 'Boeretantra' verloop in vaagheid:

Tussen die jinne en die jange

lê die korte en die lange

en tussen die lang en die korte

lê daar lankverwagte storte.

In die gedig 'Die man met die afgebrande woud' word gevra, ter wille van rym met 'was', hoe die heelal 'met soveel groen hout [kon] verkas'. 'Verkas' veronderstel dat die ganse heelal sig elders heen sou kon verplaas, wat twyfelagtig voorkom. Ook elders in die bundel word minder deurdagte woordkeuses aangetref, byvoorbeeld in 'Herdenkingsgeskenk' die woord 'verras' in die slotreël 'almal weet tog hoe 'n lem geliefdes kan verras' (rymend met 'onvanpas').

Omslagtig mededelend in 'Die man met die afgebrande woud' is byvoorbeeld die volgende: 'Met voorgeslagtelike trane is die teer grond deurdrenk, / die gekrenkte ware aard met sy inheemse sade / stoot lote uit wat grond en lug, water en vlam met mekaar verbind'. As geheel te prosaïs mededelend is die gedig 'terwyl mens wegkyk'. Vergelyk die voorlaaste strofe:

Die buurman het haar

ongedeerd na my toe teruggebring,

want hy kon deur die donker mure sien

waar sy hoort.

Onoortuigende beeldsluiting vind ' $n$ mens byvoorbeeld in die slotkoeplet van 'Daar doer in Darfoer': 'want die Duiwel se oorkussing strek / tot in die kamp se dorste hoeke'. 'Kuslyn' bevat geykte bewoording in 'tyd word 'n lyn wat omskep en ondermyn, / om opgepluk te word uit dieptes gans verlore'. In 'Argeologie' word verwys na 'die sandkorrels van tyd'.

'Ars poetica' parodieer die limeriek sonder dat die konvensies daarvan korrek nageleef of optimaal uitgebuit word. In 'Vir Astor', waarin Enrico en Maria die tango op die maat van Astor Piazzolla se musiek dans, word die grootliks geslaagde en inderdaad treffende ontginning van die distigon ontsier deur (geringer en groter) ritmiese gebreke, des te opvallender vergeleke by 'n strofe soos die derde:

Maria swaai haar heupe, maar die skouers hou sy stil -

Die bolyf word 'n dienaar van haar onderlyf se wil.

Ritmiese ongelykhede doen ook afbreuk aan byvoorbeeld die andersins heel gawe 'Tuin-ode'.
Opsommend kan gesê word dat hierdie bundel mank gaan aan willekeur, wat die leesgenot verminder. Selfs 'n fantasieverhaal besit immers bepaalde wetmatighede, anders is daar geen oortuigende spanning nie. Die gedig 'oerhoop' bevat die onbedoeld verspotte openingsreëls 'ek wil jou in 'n stilte ontmoet / wat nie ons nerwe soos goiing rasper nie' en sluit met 'n opstapeling van willekeurighede:

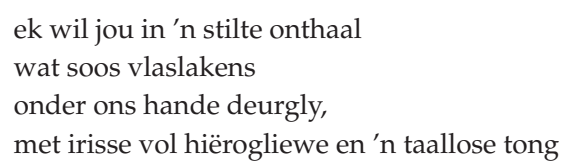

Alhoewel poësie, soos Martinus Nijhoff (1982:1154) in 'Over eigen werk' aantoon, deeglik ingegee word deur 'toewaaisels van buiten, of van binnen' en dus nie vooraf volgens ' $n$ vaste plan ontplooi kan word nie, vorm die gedig sig antisiperend in die rigting van ander se reaksie (verwant aan Mikhail Bakhtin se dialogiese beginsel). By die lees van 'n gedig, soos by die luister na 'n voordrag, geniet die leser / toehoorder dit as die ...

... spreker verlegen is, en tegelijk weet, waar hij heen wil. Een van de
grootste voldoeningen van een toehoorder is de spreker juist die woorden
te horen vinden, die ook bij hem zelf opkwamen, toen hij de spreker zag
nadenken. Zo wordt de spreker in zekere zin het instrument van zijn
gehoor, maar het instrument, in welks snaren reeds de melodieën
geborgen zijn (Nijhoff 1982:1152).

Ondanks die opvallende gerigtheid daarop om met Skryn 'n 'oop' en toeganklike aanbod te lewer, word die leser van hierdie bundel juis nie altyd voldoende in ag geneem of 'ingesluit' nie. As debuut toon Skryn in bepaalde opsigte potensiaal, maar op die keper beskou, is hierdie kissie nie netjies genoeg afgewerk nie.

\section{Literatuurverwysings}

Cloete, T.T., 1982, Jukstaposisie, Tafelberg, Kaapstad.

Cloete, T.T., 2013, Karnaval en Lent, Tafelberg, Kaapstad.

Encyclo.nl, 2016, Schrijn (8X), bekeken op 11 maart 2016 uit: http://www.encyclo.nl/ begrip/schrijn

Nijhoff, Martinus, 1982, 'Over eigen werk', in Gerrit Borgers, Gerrit \& Kamphuis, Gerrit (reds.) Verzameld werk II: Kritisch en verhalend proza, Bert Bakker, Amsterdam, bekeken op 11 maart 2016 uit: http://www.dbnl.org/tekst/nijh004verz02_01/ nijh004verz02_01_0286.php

Rousseau, Ina, 2003, Die stil middelpunt, saamgestel en ingelei deur Daniel Hugo, Human \& Rousseau, Kaapstad.

Van Niekerk, Marlene, 2013, Kaar, Human \& Rousseau, Kaapstad.

Woorden.org. 2016. de (m)/het schrijn zelfst.naamw, bekeken op 11 maart 2016 uit:it: http://www.woorden.org/woord/schrijn 